\title{
HUMAN RIGHTS LAW AND HUMANITARIAN LAW: BETWEEN COMPLEMENTARITY AND CONTRADICTION
}

\author{
Biljana KAROVSKA-ANDONOVSKA
}

\author{
Associate professor \\ Military Academy "Mihailo Apostolski" - Skopje \\ E-mail: biljana.karovska@ugd.edu.mk
}

\begin{abstract}
International human rights law and international humanitarian law are two specialized areas of the public international law, which exist as distinct legal branches. These legal branches have a different origin and legal basis, but a common humanist ideal, and consequently areas of overlap in practice. Both legal regimes share the responsibility to protect human beings' rights; Humanitarian law in time of armed conflict, human rights law in peacetime and in wartime as well. Because of this, in practice there is sometimes concurrent application of the legal norms of international human rights law and international humanitarian law. At the same time, there are also differences between these two legal regimes that arise from the different circumstances which are relevant in a state of peace and in state of war. Hence, regarding this relationship, many relevant questions arise: Whether these legal branches are mutually exclusive? Under what circumstances does humanitarian law apply, and how does this differ from the applicability of human rights law? Which are the areas of overlap? What are the practical consequences of the legal issues resulting from parallel application of the two legal frameworks?

This paper is not intended to resolve all these questions, but to make contributions in the ongoing debate by presenting similarities between human rights law and humanitarian law, areas of overlap, and situations of concurrent application. We will also underline the differences which exist in this relationship, especially the differences in the scope of protection guaranteed within the legal norms, the responsibility for breaking the norms, as well as permitted derogations in implementation of the norms. One part of the paper applies the principle lex specialis in cases where one of the legal branches is more specific in a concrete situation.
\end{abstract}


Key words: International human rights law, international humanitarian law, relationship, armed conflict, human rights

\section{Introduction}

International human rights law (IHRL) and international humanitarian law (IHL) are legal branches that arise from the international public law, which regulates the relations between states, and relations between states and international organizations. IHRL is focused on the international protection of life, integrity, liberty, privacy, and other human rights and freedoms. On the other hand, IHL regulates the principles of warfare and the rules which limit the means by which armed conflicts can be undertaken, in order to prevent inhumane acts and human suffering. This is one of the reasons why some authors argue that IHRL and IHL are not two separate realms of law, but rather two expressions of the same corpus juris (Casla, 2012, p.2). There is no doubt that these legal regimes have concern for humanity at their essence and strive to impose this concern as an imperative through legally binding international documents. To say that IHRL is applicable not only in times of peace but also in armed conflict is a cliché today (Szpak, p. 303) but, certainly it is not enough to claim that IHRL does not disappear when a war takes place (Casla, 2012, p. 2). However, the relationship between IHL and IHRL is important as it influences the protection accorded to human beings in such circumstances as a state of peace and of an armed conflict (Szpak, 2014, p. 303). The application of IHRL and IHL in situations of armed conflict has raised questions, especially regarding concurrent application of their norms. This application sometimes could create confusion about the obligations and extent of those obligations as applied to the parties to a conflict, the standards to be applied, and the beneficiaries of these protections. On the other hand, human rights undoubtedly are gravely damaged in armed conflicts (loss of human lives, injury to individuals and destruction of property, as well as many other violations of basic human rights). Because of these reasons, IHRL and IHL should interact in the most effective way. Hence, in some situations they are applicable in a complementary manner. Moreover, expansion of the scope of application of IHRL, combined with the monitoring machinery and individual complaints procedures existing in the human rights system, have led to the recognition that human rights, by their nature, protect persons at all times and therefore are relevant and should be applied also in situations of armed conflict (Droege, 2007, p. 312).

The debate regarding the relationship between these legal branches has been intensified, especially regarding contemporary armed conflicts in which serious violations of IHRL and IHL are common. Some violations may even constitute genocide, war crimes or crimes against humanity. All logically possible positions concerning a relationship between the two poles of IHL and IHRL have been defended in legal writings. Robert Kolb had classified these positions into three groups (Kolb, 2012, p. 6): 
"Separatists" who cling to a traditional view of both branches as it existed immediately after World War II. They essentially fear a politicization of IHL by IHRL and refuse any closer connection between the two on that basis;

"Complementarists" who take the idea that both branches have different roots, approaches, and so on. These thinkers are ready to admit a complementarity between both on specific points where the one can be called on in order to complete the other;

"Integrationists" who are prepared to further push the merger between the two branches.

As a contribution to the ongoing debate, this article provides a brief overview of the historical developments that led to the increasing overlap between IHRL and IHL, and explains the author's views regarding interrelationship in the context of implementation of the rules and principles of IHRL and IHL, particularly in the context of implementation in practice.

\section{Origin and legal basis of IHRL and IHL}

IHRL and IHL are traditionally two distinct branches of the law which had different origins and legal foundations. However, from a legal perspective, both IHRL and IHL find their source in a series of international treaties, which have been reinforced and complemented by customary international law.

The history of IHL indicates that military rules have ancient origins, probably since the Chinese military treatise "The Art of War", attributed to the ancient Chinese military strategist Sun Tzu and dating from roughly $5^{\text {th }}$ century BCE. Military and humanitarian rules were rewritten from one war to another as new rules replaced the old. Currently, IHL is a set of international rules specifically intended to solve humanitarian problems which directly arise from armed conflicts, both international and intra-national. The rules of IHL deal with the conduct of parties in an armed conflict and many issues that are outside the purview of IHRL, such as conduct of hostilities, prisoners of war status. IHL actually contains international rules, established by treaties or customs, specifically designed to address humanitarian issues directly arising from armed conflicts, international or intra-national. These rules, citing humanitarian reasons, restrict the right of the parties to an armed conflict to use the methods and means of warfare of their choice. The legal foundation of the IHL covers both the "Hague Law", based on the rules adopted on The Hague Peace Conferences from 1899 and 1907, dedicated on the means and methods of warfare, and the "Geneva Law" based on the Geneva Conventions I-IV from 1949 , dedicated to the protection of victims of armed conflicts, as well as on their 1977 Additional Protocols. These basic documents were upgraded by a number of other international legal acts which provide for a ban on the use of nuclear and thermonuclear weapons (1961), a ban on nuclear proliferation (1967), ban on the development, production and storage and destruction of toxic weapons (1972), ban on the development, production, storage and use of chemical weapons and the means of their destruction (1993), ban on nuclear 
tests (1996), ban on the use, storage, production and transfer of anti-personnel mines and their destruction (1997). The aim of IHL primarily is to protect persons who are not or are no longer taking part in hostilities, the sick and wounded, prisoners and civilians, and to define the rights and obligations of the parties to a conflict in the conduct of hostilities (International Committee of the Red Cross, 2010). Hence, the primary motivation in development of IHL was a principle of humanity, not a principle of rights, and its legal development was made possible by the idea of reciprocity between states in the treatment of the other states' troops (Droege, 2007, p. 313). However, in the $21^{\text {st }}$ century, IHL more clearly enunciated its association with human rights law (Alexander, 2015).

While humanitarian law, by its very nature, took root in the relationship between states, "human rights were, in their beginning, a matter of constitutional law, an internal affair between the government and its citizens" (Droege, p. 312-313). It remained a subject of national law until conclusion of the Second World War when through the United Nations, human rights became part of international law. The idea of respect for human rights and freedoms on the international level was developed as a result of the evolution of human consciousness to create a humane society where each individual as a free being will exercise their individual and collective rights. One of the reasons for this evolution was the fact that both world wars, especially World War II, were part of the tragic history of mankind with violations of basic human rights and freedoms on a vast and, until then, unprecedented scale.

Today, the idea of human rights is developed to the point of being understood as the most basic value system, accepted by most countries and cultures, as a benefit to civilization. The generally accepted standard is the absoluteness of certain personal rights, the right to life, the right to freedom from torture, inhuman or degrading treatment or punishment, the right to legal certainty of criminal offenses and penalties, the right to freedom of conscience, beliefs, and conscience, which cannot be reduced and must be respected regardless of the circumstances, even in wartime and other emergencies. IHRL is actually a set of international rules established by binding legal acts, on the basis of which individuals and groups can expect and demand certain rights be respected and protected by their states. The global human rights protection system was established by the UN Universal Declaration of Human Rights of 1948, later developed with a number of significant legal documents, which protects a certain set of rights, such as International Covenant on Civil and Political Rights and the International Covenant on Economic, Social and Cultural Rights (1966), Convention on the Prevention and Punishment of the Crime of Genocide (1951), Convention for Non-obsolescence of War Crimes and Crimes Against Humanity (1968), Convention for Elimination of All Forms of Racial Discrimination (1969), Convention for Elimination of All Forms of Discrimination Against Women (1979), Convention of the Rights of the Child (1989). The set of the international legal norms and standards are also incorporated into the national systems of the states, which should guarantee and ensure their observance and proper application. The effective application of 
these norms is ensured through appropriate mechanisms and international institutions. The IHRL sets out the obligations of states, through their institutions, to act in a certain way or to refrain from taking certain actions in order to promote and protect the human rights and fundamental freedoms of individuals or members of certain groups. Numerous non-treaty-based principles and guidelines (soft law) also belong to the body of international human rights standards. Under public international law, states undertake to respect and protect the human rights of their citizens and of all persons within the territory of a particular State. The obligation to respect human rights means that states must refrain from interfering with or restricting the exercise of human rights. This obligation also means that states must take concrete action to facilitate the enjoyment of human rights, as well as refrain from acting when it is a prerequisite for an individual to be able to exercise his or her rights. Even for the realization of these specifically determinate rights (so-called negative rights) the realization of which presupposes non-interference or inaction of the state government, the state still should create adequate conditions for individuals to be able to exercise those rights.

\section{Differences and similarities between IHRL and IHL}

IHRL and IHL as branches of law which arise from international law and exist as distinct legal branches, constitute a whole, and although they are not identical, they complement each other. However, in the end, they remain distinct (See: Szpak, 2014, p. 304). From this relationship the following important question arises: What is it that connects and brings together these two branches of law, and what are the differences between them that condition their existence as separate legal regimes? First, there are differences between IHRL and IHL that arise from the different circumstances which are relevant in a state of peace and in state of war. The most important difference is probably the scope of protection guaranteed with their norms. In IHL the protection depends on the category to which a person belongs, e.g., the protection of civilians is not the same as the protection of combatants. On the other hand, under IHRL all human rights for all human beings are guaranteed, although there are some instruments established to protect specific rights for specific categories of persons, e.g., children, women, persons with disabilities or migrants.

Another difference between these branches of the law is the fact that, in IHRL states are responsible for breaches, while in IHL breaches engage the responsibility not only of states but also the criminal responsibility of individuals. In addition, because of the fact that IHL deals with exceptional situations, as armed conflicts, no derogations whatsoever from its provisions are permitted. On the other hand, IHRL applies in peacetime and although those rules do not disappear even in war, its rules permit governments to derogate human rights in a situation of emergency. There is an exception regarding certain human rights which have a special status as peremptory norms of 
international law (ius cogens), and no derogation is admissible under any circumstance, because they prevail over other international obligations.

Finally, IHRL covers almost all human rights while some of these rights are not relevant for IHL, though there is set of human rights which may be matters for IHRL and IHL in the same time. Moreover, recent treaties include provisions from both bodies of law, for example the Convention on the Rights of the Child and its Optional Protocol on the Participation of Children in Armed Conflict, and the Rome Statute of the International Criminal Court (ICRC, 2003, p.1). In addition, certain violations of human rights and humanitarian law constitute crimes under international criminal law, so other bodies of law, such as the Rome Statute of the International Criminal Court, could also be applicable. International criminal law and criminal justice on war crimes implement international humanitarian law, but they also clarify and develop its rules. Similarly, other bodies of law, such as international refugee law and domestic law, will also often be applicable and may influence the type of human rights protections available (UN Human Rights Office of the High Commissioner, 2011, p. 8).

On the other hand, beyond their different historical backgrounds, normative specificities and scope of protection, these legal branches have a common humanist ideal, and consequently areas of overlap in practice. Both legal regimes share the responsibility to protect human beings' rights and have common aims in the protection of persons' integrity and dignity. Moreover, both legal regimes, among other things, provide protection for some vulnerable categories as children and women. Hence, according to some authors, a real turning point in the unique treatment of human rights was made by the 1989 UN Convention on the Rights of the Child (Vasilevski, 2002, p. 42). According to Article 38 of this Convention "States Parties shall take all feasible measures to ensure that persons who have not attained the age of fifteen years do not take a direct part in hostilities; shall refrain from recruiting any person who has not attained the age of fifteen years into their armed forces; and, shall take all feasible measures to ensure protection and care of children who are affected by an armed conflict."(UN Convention on the Rights of Child, 1989). Special protection of children in situations of military conflicts is also provided by IHL. Provisions from the UN Convention on the Rights of the Child are complementary to the provisions of the 1949 Geneva Convention for the Protection of Civilians, which in Article 24 provides for an obligation for states to take appropriate measures in favor of children in time of armed conflict, in particular children under fifteen years, children without parents or separated from their families, as well as in Article 50 regarding the care and custody of children in time of war. Moreover, Additional Protocol I to the Geneva Conventions on the Protection of Victims of International Armed Conflict also contains special provisions for the protection of children, as well as provisions for their evacuation in time of an armed conflict. 
We can sum up the similarity between IHRL and IHL's rules, some of which are even identical, as follows. These two branches of law have identical guarantees such as protection of the right to life, the prohibition of discrimination, torture, and cruel treatment. The pursuit of full and adequate protection of victims of armed conflicts brings these two legal branches closer and is the reason for their functional connection and interdependence.

\section{Interrelationship in the context of implementation}

According to some authors, the relationship between IHRL and IHL is paradoxal in the sense that there is an increasing awareness on the part of the international community of the convergence between these two sets of norms, while there is also an unexploited potential of complementarity (Hampson, F. and Salama, I., 2005, p. 4). The application of IHRL in situations of armed conflict could be complicated in practice because of some of the following questions. What is the territorial applicability of the IHRL and IHL norms? What are the differences in the ways IHRL and IHL protect persons? What is the extent to which IHRL can be applied to armed conflicts taking place outside the territory of the parties concerned? Are non-state parties bound to apply IHRL in non-international armed conflicts? To what extent may States derogate from certain of their obligations under IHRL? However, applying IHRL or IHL instead of the other, or both at the same time, can provide radically different results and create issues for the protection of the people concerned (Sasoli, M., Lubell, N., Breitegger, A., 2017). Important questions for the relationship between IHRL and IHL in context of practical implementation is the question whether states are bound to comply with their international human rights obligations only on their own territory. According to the content of the international legal documents, there is no doubt that most human rights apply not only to citizens but also to foreigners. Hence, although sometimes it has been contested that conventional human rights obligations bind states outside their territory, today it is uncontroversial that everyone, everywhere in the world, benefits from human rights and therefore it is logical to assert that states should be bound to comply with their obligations in respect of all persons under their jurisdiction, irrespective of whether they are in their territory (UN Human Rights Office of the High Commissioner, 2011, p. 42-45).

Because these branches of the law have common aims and identical guarantees, there are some areas of overlap in practice, where both IHRL and IHL can be applicable in parallel, and sometimes in complementary ways. One of the areas of overlap of the IHRL and IHL's norms refers to the situations of occupation. The main question regarding this situation is the question of the respect of basic human rights, and the question of the application of basic legal international documents for human rights in an occupied territory.

Although at the time the UN Universal Declaration was adopted, there were probably no assumptions that the question of respecting human rights is also relevant in situations of armed conflicts, later this question became a topic to 
which UN referred. Since 1967, when Israel occupied the Palestinian territories, through the military conflicts that happened later, the question of human rights in context of these kinds of conflicts was continuously discussed. In the territories occupied by Israel after the Six Days War, the new approach of mixing IHRL and IHL for the protection of civilians has been applied up to the present time (Kolb, 2012, p. 4). UN officially accepted the application of the human rights principles and rules with adoption of resolutions where members were called to apply not only Geneva Conventions, but also the Universal Declaration in periods of armed conflicts and in the occupied territories where humanitarian principles must prevail. Through the 1973 UN Resolution "Respect for human rights in armed conflicts", all parties to armed conflicts were called to comply with their obligations under the humanitarian instruments and to observe the international humanitarian rules which are applicable (GA resolution 3102). Issues keep arising in situations of civil wars, international armed conflicts, proxy wars or other kinds of modern armed conflict, be it in Syria, Nagorno-Karabakh, or other places.

Situations of non-international armed conflicts are another interesting area for the relationship between IHRL and IHL in practice. Sometimes there is no red line between international and non-international armed conflicts because the conflict could begin as typically non-international, and grow into a conflict with international elements. However, in situations without international elements, IHRL probably could be easily apply because civil war takes place within a state which continues to be bound by human rights documents and instruments. According to some authors, in non-international armed conflicts the only step that must be taken is to define which human rights are applicable only in peacetime, and which ones are applicable also in times of emergency. According to Kolb, from there, a doctrine of non-derogable human rights, which remain applicable in cases of armed conflict and other situations of emergency, was developed (Kolb, 2012, p. 4). The 1949 Geneva Conventions Article 3 is dedicated to non-international armed conflict through which the first systematic regulation of internal conflicts was introduced. According to its content, in the case of non-international armed conflicts, each party to the conflict should apply, as a minimum, the provisions that guarantee humane treatment of persons who do not take an active part in the hostilities, including members of armed forces who have laid down their arms as well as the sick and wounded or prisoners. This Article also prohibits at any time and in any place whatsoever "violence, cruel treatment and torture; taking of hostages; outrages upon personal dignity; the passing of sentences and the carrying out of executions without previous trial by a regularly constituted court" (Geneva Conventions, 1949). Moreover, Protocol II to the Geneva Convention is dedicated to non-international armed conflict. This Protocol is important because it is the first legal instrument which admits the parallel application of the IHL rules with the rules of IHRL.

Here we can see a growing trend in covering IHL issues within the framework of a joint IHL and IHRL perspective. This is important, among other things, because of the fact that violating IHL means violating human rights at the same 
time, while respecting IHL rules does not necessarily ensure respect for all human rights. Approaches and methodologies in this respect vary according to the particularities of the current situation. In this regard, we agree with the opinion of most of the authors, that both regimes of law can be appliedin armed conflicts in order to achieve the greatest possible protection. Moreover, nothing in human rights treaties indicates that they would not be applicable in times of armed conflict (UN Human Rights Office of the High Commissioner, 2011, p. 6). Although there are also authors who consider that very few scholars or advocates have put forward concrete examples of the substantive, normative contribution of human rights law application (See: Bohrer,2015).

The most important practical influence of this relationship is the possibility to enforce IHL as a legal regime in time of military conflicts. Or, according to some authors, the added value of applying IHRL in armed conflict is that it may fill the gaps present in IHL concerning individual remedies (Todeschini, 2018, p. 1). The UN Security Council, for example, increasingly addresses IHL and IHRL jointly. The Security Council invited the Secretary-General to refer to the Council information and analyses from within the UN system on cases of serious violations of International law, including IHL and IHRL. In addition, according to the general comment on Article 4 of the UN International Covenant on Civil and Political Rights, regarding the derogations during a State of Emergency, where situation of war is not mentioned, the Human Rights Committee explains that "during an armed conflict, whether international or non-international, rules of international humanitarian law become applicable and help, in addition to the provisions in article 4 and article 5, paragraph 1, of the Covenant, to prevent the abuse of a State's emergency powers"(General comment, 2001, No. 29). Moreover, according to this general comment, Covenant applies also in situations of armed conflict to which the rules of IHL are applicable. In respect of certain Covenant rights, more specific rules of IHL may be especially relevant for the purposes of the interpretation of Covenant rights, both spheres of law are complementary, not mutually exclusive (General Comment, 2004, No. 31 [80]). The relevant question is also whether the Covenant applies to a state party's actions beyond the confines of its borders. We can agree with the opinion of Trevor Keck that the prevailing view is that the Convention may apply extraterritorially in certain circumstances having in mind the provision stipulated in Article 2 (1), according to which, each state party "undertakes to respect and to ensure to all individuals within its territory and subject to its jurisdiction the rights recognized in the present Covenant, without distinction of any kind." In addition, Keck underlines that human rights obligations, such as norms concerning the security and protection of individuals, have attained the status of customary international law and basic human rights norms are considered rights erga omnes (Keck, 2012, p. 158). Hence, all states should secure protection, and customary human rights obligations, such as the prohibition of arbitrary killings, should apply always and everywhere. Application of these norms does not turn on whether the Covenant applies to the territory or individual in question. 
Among these areas of overlap or parallel application, there are controversial examples in practice that sometimes open the dilemmas whether IHRL and IHL in some cases are better to be complimentary or mutually exclusive? We can see it through the different mechanisms of enforcement of IHL on international and regional level. One of the examples is the exemption of United States personnel from International Criminal Court jurisdiction and the conclusion of the so-called 'article 98 agreements' or impunity agreements which the US concludes with third countries. Those are bilateral agreements between the US and other states (members and non-members to the Rome Statute) agreeing not to surrender possible suspects to the International Criminal Court. The debate on whether these agreements are legal or not under international law, is still open, although the objective of the Rome Statute is actually to end impunity. As another example, similar to this, was the situation when European Union has been trying to put up cooperation agreements known as 'status agreements' between FRONTEX and EU candidate countries, which foresee a clause for immunity from criminal jurisdiction for acts carried out by FRONTEX personnel from the jurisdiction of the counterparty.

However, the crimes which are potentially prosecuted by the International Criminal Court are part of the principle of Universal jurisdiction, as crimes of high concern for the international community that cannot stay unpunished. Prosecuting these crimes is recognized by the ius cogens, and consequently International Criminal Court should legally prosecute these crimes even if the nationality of the person to be potentially prosecuted is not a part of the Rome Statute.

\section{Application of the principle lex specialis}

Respect for human rights in the context of armed conflict presupposes a balance between the universality of human rights, on the one hand, and considerations of effectiveness, on the other, just as the IHL itself embodies a balance between humanitarianism and military need. The complementary application of the two legal regimes is known as concurrent application or dual applicability and in the context of IHRL and IHL, it means that both legal regimes are applicable in times of armed conflict (UN Human Rights Office of the High Commissioner, 2011, p. 56). According to Marko Milanovic, the corpus of human rights law, developed over decades by courts and treaty bodies, primarily in normal times, must be adjusted and applied more flexibly in extraordinary situations in order to avoid imposing excessive, unrealistic burdens on states, although that must not go too far, so as to render them completely ineffectual or to compromise the integrity of the regime as a whole (Milnovic, 2014, p. 36). However, Milanovic also underlined that there are instances where this quest for harmony will fail, when the two bodies of law cannot be reconciled, when all legitimate methods of norm conflict avoidance and resolution will be exhausted, and when ultimately a political choice will have to be made as to which of the conflicting norms should be given priority over the other (See: Milanovic, 2010). 
Because of similar protections that IHRL and IHL offer, their parallel application in practice does not, in general, raise some serious problems. However, sometimes these legal regimes may offer contradictory solutions or simply, regulate the same situation in a different manner. The situations in which the IHRL and IHL regimes offer different solutions or where the application of different norms yield different results is small compared to situations where both regimes provide similar protections. In such cases of conflict of legal norms or procedures, the important question is: Which regime of law is the more specific? That kind of situation could be resolved through the mechanisms of legal interpretation, as lex specialis. The principle of lex specialis is applicable only when there is an apparent conflict between two norms that could be applied to a specific situation and this principle does not admit of automatic application. The Human Rights Council, for example, in its resolution for Protection of the Human Rights of Civilians in Armed Conflict acknowledged that human rights law and international humanitarian law are complementary and mutually reinforcing and that the protection provided by human rights law continued in armed conflict, taking into account when international humanitarian law applied as lex specialis (UN Human Rights Council Resolution 9/9). According to Cordula Droege, the interplay of both bodies is slowly being tested in practice, mainly in national and international courts, and a framework for their interplay is the complementarity approach, necessarily limited by the lex specialis principle (Droege, 2007, p. 355). The identification of which rule will have pre-eminence depends on an examination of the facts and of the particular protection included in the relevant rules (UN Human Rights Office of the High Commissioner, 2011, p. 61). For example, even in a time of armed conflict, many human rights violations are not a direct result of hostilities and should be resolved by applying national law and international human rights law. International humanitarian law is not applicable in that situation. According to Kolb, "rather than stressing mutual exclusiveness, be it specialty or priority, it would be better to focus on two aspects: a) gap filling and development of the law by co-ordinate application of norms of HRL in order to strengthen IHRL and vice versa; b) interpretation allowing an understanding of one branch in the light of the other normative corpus in all situations where this is necessary, i.e. in armed conflict or occupation" (Kolb, 2012, p. 9).

There is also another suggested approach for identifying the precedent of the IHRL and IHL rules with application of the lex specialis principle. According to Keck, IHL is lex specialis in international and high intensity armed conflicts, while norms of IHRL should govern the use of force in military occupations, low-intensity asymmetric conflicts and more generally in situations where armed forces exercise "effective control" over territory (Keck, 2012, p. 157). Finally, the efforts for identifying the interrelationship between IHRL and IHL in the context of implementation, even in situation of possible contradictory solutions, could be supplemented with some kind of sublimate from the case law approach, given in working paper by Hampson and Salama (Hampson and Salama, 2005, p. 19): 
- IHRL, subject to possible derogation, remains applicable in situations in which IHL is applicable;

- In situations of conflict, particularly situations arising on the battlefield, human rights bodies should interpret the norms of IHRL in the light of IHL, as the lex specialis;

- Difficulties are likely to arise if a human rights body fails to take IHL into account;

- It appears unlikely that the persistent objector principle is applicable, either in principle or on the facts; and

-Members of treaty bodies and those relevant special procedures should either have training in IHL if they think they need it or should have/IHL expertise available to them.

\section{Concluding remarks}

The relationship between IHRL and IHL could be expressed thus: complementarity between their norms in most cases; and prevailing of the more specific norm when there is contradiction between the two branches. It is no doubt that both the IHRL and the IHL offer protection of a human being's rights in time of conflict, and IHRL does so in peacetime, as well. Hence, IHL and IHRL share a common ideal and many of their guarantees are identical. The basic and common ideal is regarding protection of human dignity and integrity, protection of human life, freedom from torture and ill treatment, protection of family rights, economic, social and cultural rights.

Hence, these two legal branches are related and should interact in a manner that leads to synergy. The parallel application of IHL and IHRL, and the principles that should govern the interplay between these two bodies of law, continues to be the subject of debate. Many authors agree that IHL and IHRL, should be applied together to a situation so as to leave no gaps and to obtain a mutual strengthening. The international community no longer accepts gaps in protection, particularly in situations where civilians, especially women and children, are subject to attacks, which is the prevalent problem in contemporary armed conflicts. Human rights protection shares not only a common philosophy with humanitarian law, but can also be used to compensate for the deficits of their legal basis. However, we cannot speak as for identical branches of law, but branches that although may take significantly different forms, still address a similar range of concerns. These branches overlap in some situations, such as situations of occupation or in non-international armed conflicts, and they still often do that in complementary way. On the other hand, although they share the same goals, they still remain distinct. For these reasons, the question of the relationship between IHRL and IHL could also be objectively seen through practice and past experiences. Today, IHRL remains applicable in all circumstances, although in a modified way because of the specificities that arise from different kind of armed conflicts. Nevertheless, IHRL and IHL are not two contradictory and wholly distinct systems of law, rather they complement each other in a way that mutually benefits from their contents. Moreover, as has been 
definitely recognized by international and regional courts, as well as by UN organs and treaty bodies, both legal regimes apply to situations of armed conflict and provide complementary and mutually reinforcing protection.

\section{References}

Advisory service on International Humanitarian Law (2003) International Humanitarian Law and International Human Rights Law - Similarities and differences, ICRC

Alexander, A. (2015) A Short History of International Humanitarian Law, European Journal of International Law, Volume 26, Issue 1

Bohrer, Z. (2015) Human Rights Vs Humanitarian Law or rights vs obligations: Reflections following the rulings in Hassan and Jaloud, Questions of International Law Journal, Vol II/2015, Napoli

Casla, K. (2012) Interactions between international humanitarian law and International human rights law for the protection of economic, social and cultural rights, Revista Electronica De Estudios Internacionales

Droege, C. (2007) The interplay between international humanitarian law and international human rights law in situation of armed conflict, The

Hebrew University of Jerusalem Faculty of Law, Research Paper No. 14-07, pp. 310-355

GA resolution 3102 (XXVIII) - Respect for human rights in armed conflicts, retrieved from: https://www.un.org/unispal/document/auto-insert186457/ (accessed 06/06/2021)

Geneva Conventions (1949) International Committee of the Red Cross, Geneva, Switzerland

Hampson, F. and Salama, I. (2005) Administration of justice, rule of law and democracy - Working paper on the relationship between human rights law and international humanitarian law, United Nations, Geneva

International Committee of the Red Cross (2010) War and International Humanitarian Law, retrieved from: www.icrc.org/eng/war-andlaw/overview-war-and-law.htm(accessed 06/06/2021)

Keck, T.A. (2012) Nor All Civilians Are Equal: The Principle of Distinction, The Question of Direct Participation in Hostilities and Evolving Restrains on the Use of Force in Wartime, Military Law Review, No. 211, p. $115-178$ 
Kolb, R. (2012) Human rights and humanitarian Law, Max Planck Institute for Comparative Public Law and International Law, Heidelberg and Oxford University Press

Milanovic, M. (2014) The Lost Origins of Lex Specialis: Rethinking the Relationship between Human Rights and International Humanitarian Law, SSRN, retrieved from: https://papers.ssrn.com/sol3/papers.cfm?abstract_id=2463957(accesse d 06/06/2021)

Milanovic, M. (2010) Norm Conflicts, International Humanitarian Law and Human Rights Law, Human Rights and International Humanitarian Law, Collected Courses of the Academy of European Law, Vol. XIX/1, Orna Ben-Naftali ed., Oxford University Press

Sasoli, M., Lubell, N., Breitegger, A. (2017) Recent developments of the interplay between IHL and IHRL, International Committee of the Red Cross

Szpak, A. (2014) International Humanitarian Law and International Human Rights Law before ICTY - Contradictory or Complementary Legal Systems, International Conference for Academic Disciplines, Ca'Foscari University, Venice, Italy, p. 303-310

Todeschini, V. (2018) Redressing Unlawful Use of Force in Armed Conflict: The Role of International Human Rights Law, published in: Kurt Mills and Melissa Labonte (eds), Accessing and Implementing Human Rights and Justice (Routledge 2018)

UN Convention on the Rights of Child (1989), retrieved from:https://www.ohchr.org/en/professionalinterest/pages/crc.aspx (accessed 06/06/2021)

UN Human Rights Committee, General comment (2001) No. 29, States of emergency (article 4): International Covenant on Civil and Political Rights

UN Human Rights Committee, General Comment (2004) No. 31 [80] The Nature of the General Legal Obligation Imposed on States Parties to the Covenant

UN Human Rights Office of the High Commissioner (2011) International legal protection of human rights in armed conflict, UN Publication, New York and Geneva 
UN Human Rights Council Resolution 9/9 - Protection of the human rights of civilians in armed conflict, retrieved from: https://ap.ohchr.org/Documents/E/HRC/resolutions/A_HRC_RES_9_ 9.pdf (accessed 06/06/2021)

Vasilevski, V. (2002) International Humanitarian Law, Military Academy "General Mihailo Apostolski", Skopje 
